\title{
ANALISIS EFEKTIVITAS RUANG HENTI KHUSUS (RHK) SEPEDA MOTOR MODEL STARTING GRID PADA SIMPANG BERSINYAL DI TAMAN MULI - MEKHANAI (TAMAN KOTA LUNGSIR) KOTA BANDAR LAMPUNG DI MASA PANDEMI COVID - 19
}

Aditya Mahatidanar ${ }^{1}$

Muhammad Hafiz Saktiadi²

Fakultas Teknik Universitas Bandar Lampung

Jl. Zainal Abidin Pagar Alam No.26, Labuhan Ratu, Kedaton,35142,Bandar Lampung, Indonesia

Email : Adityamahatidanar@dosen.ubl.ac.id; m_hafiz.15311077@student.ubl.ac.id

\begin{abstract}
ABSTRAK
In the performance of intersections with signals, traffic lights play an important role in their performance, and motorcycle RHK (Special Stopping Rooms) is one of the solutions to help the performance of the intersection with signals running well. And during the 2019 Corona Virus Disease Pandemic, the role of RHK was very influential on the spread of the virus, therefore the government, Traffic Police and Transportation Agency collaborated to improvise the RHK by adding a Starting Grid Mark to the RHK. This study analyzes the effectiveness of RHK with Starting Grid markers by calculating the violation rate and RHK filling levels with starting grid markers. The analysis is carried out on Weekend and Weekdays during the morning, afternoon and evening rush hour. Obtained data. On weekdays RHK 1 morning 89.57\%, noon, 62.5\% and 50.99\% afternoon, while at Wekeend RHK 1 morning $71.74 \%$, 55.3\% afternoon and $60.1 \%$ afternoon. From the results of this research, at the intersection of the city park lungsir bandar Lampung, it works effectively, can reduce the length of queues and can minimize the spread of Corona Virus Disease 2019.
\end{abstract}

Keyword : Analysis of the Effectiveness of a special Stopping Room (RHK) for motorbikes at a signalized intersection; RHK Motorbikes during the COVID-19 pandemic 


\section{PENDAHULUAN}

Provinsi Lampung adalah salah satu provinsi yang ada di indonesia, Bandar Lampung adalah ibu kota sekaligus kota terbesar di Provinsi Lampung. Selain Medan dan Palembang yang merupakan jumlah Kependudukanya terbesar di pulau Sumatra adalah Provinsi Lampung terutama kota Bandar Lampung. Kota Bandar Lampung terbagi kedalam 20 Kecamatan dan 126 Kelurahan dengan populasi penduduk 1.015.910 jiwa (berdasarkan data tahun 2017). Dengan meningkatnya populasi penduduk dari tahun pertahun mengakibatkan bertambahnya jumlah pengendara khususnya kendaraan sepeda motor. Pertumbuhan ini secara langsung berpengaruh pada bertambahnya pengguna jalan. Menurut Badan Pusat Statistik (BPS) Provinsi Lampung, jumlah kendaraan sepeda motor khususnya di Kota Bandar Lampung mencapai 730.946 unit di tahun 2019. Dikarenakan pertumbuhan Sepeda Motor di Kota Bandar Lampung sangatlah pesat maka meningkatnya rasio dan resiko penumpukan kendaraan sepeda motor pada lokasi-lokasi tertentu, seperti persimpangan atau perempatan pada fase lampu merah pengatur lalu lintas.

Pesatnya pertumbuhan jumlah kendaraan sepeda motor tanpa diikutinya peningkatan kualitas infrastruktur dan sarana atau sistem transportasi, berdampak pada turunya kinerja persimpangan bersinyal. Pemerintah yang di wakili oleh Balitbang PUPR menghadirkan teknologi untuk mengatasi penurunan kinerja pada persimpangan bersinyal dengan menghadirkannya Ruang Henti Khusus (RHK) sebagai salah satu solusi. Adapun fungsi dari Ruang Henti
Khusus (RHK) untuk membantu sepeda motor langsung menuju persimpangan dengan mudah dan aman, lebih dahulu dari kendaraan beroda 4, sehingga langsung berada di bagian depan dari jalan. Karena berada posisi paling depan maka saat lampu lalu lintas berwaran hijau kendaraan sepeda motor dapat bergerak cepat meninggalkan persimpangan sehingga membuat persimpangan bersih, sehingga kendaraan beroda 4 dapat bergerak secara laluasa. Rekayas Lalu lintas dengan teknologi Ruang Henti Khusus (RHK) ini diyakini dapat memperbaiki kinerja di persimpangan bersinyal menjadi lebih efektif dan efisien.

Pada Tahun 2020 Indonesia mendapatkan Musibah yaitu datangnya wabah Virus Corona Disease 2019 (COVID-19) yang merupakan masalah besar untuk Negara Indonesia maupun Seluruh Dunia. Dengan penyebaran virus ini yang begitu cepat dan penanganannya masih dalam penilitian begitu juga vaksinnya belum ditemukan. Pemerintah mengambil sikap tegas dengan adanya Covid-19 ini melalui Permenkes No.09 tahun 2020 Tentang Pedoman Pembatasan Sosisal Berskala Besar dalam Rangka Percepatan Penanganan Corona Virus Disease 2019 (COVID-19). Dengan adanya peraturan ini seluruh warga negara indonesia diwajibkan menjaga jarak satu sama lain agar penyebaran virus ini tidak terlalu cepat. Oleh karena itu Pemerintah Daerah dan Direktorat Lalu Lintas berkerjasama untuk menangani Covid-19 ini dengan cara improvisasi terhadap Ruang Henti Khusus (RHK) Sepeda Motor dengan penambahan marka dengan model Starting Grid. Starting Grid tersebut dibuat dengan jarak 1 meter agar pengendara satu dan pengendara lainnya tidak terlalu dekat sesuai dengan peraturan pemerintah di 
masa Pandemi ini. Pada simpang bersinyal di Kota Bandar Lampung yaitu Simpang Lungsir (Taman Kota) pada Jln. Dipenogoro dan Jln. Dokter Susilo merupakan simpang bersinyal yang sudah menerapkan Marka Starting Grid pada RHK sepeda motor. Oleh karena itu perlu adanya suatu evaluasi mengenai tingkat keberhasilan penerapan teknologi Ruang Henti Khusus (RHK) sepeda motor dengan Model Starting Grid pada persimpangan bersinyal simpang Lungsir (Taman Kota) Jln. Dipenogoro dan Jln. Dokter Susilo.

\section{TINJAUAN PUSTAKA}

Dalam analisis ini ditinjau dari Sistem Jaringan jalan yaitu sebuah kesatuan ruas jalan yang saling berhubungan dan saling mengikat satu sama lain sebagai pusat pertumbuhan dengan wilayah yang berada dalam pengaruh pelayananya yang mencangkup suatu hubungan hierarkis. Dan didalam sistem jaringan jalan ada simpang bersinyal yaitu sebuah persimpangan yang terdiri dari beberapa lengan dan dilengkapi dengan pengaturan sinyal lampu lalu lintas (traffic light). Tujuan dari simpang bersinyal tersebut yaitu :

a. Untuk menghindari kemacetan simpang akibat adanya konflik arus lalu - lintas, sehingga terjamin bahwa suatu kapasitas tertentu dapat dipertahankan, bahkan selama kondisi lalu - lintas jam puncak.

b. Untuk memberi kesempatan kepada kendaraan dan/ atau pejalan kaki dari jalan simpang (kecil) untuk memotong jalan utama.

c. Untuk mengurangi kecelakaan lalu - lintas akibat tabrakan antara kendaraan dari arah yang bertentangan.

Oleh karena itu terciptalah teknologi RHK (Ruang Henti Khusus) Sepeda Motor yang sebagaimana dimaksud adalah Teknologi rekayasa lalu lintas yang dihadirkan oleh Balitbang PUPR sebagai salah satu solusi untuk mengatasi penurunan kinerja lalu lintas pada persimpangan bersinyal, sehingga lalu lintas pada simpang menjadi lebih efektif dan efisien. Pada Tahun 2020 sejak awal tahun pada bulan Februari Indonesia mendapatkan sebuah Musibah dengan munculnya wabah Corona Virus Disease 2019 dan disebut sebagai COVID19. Dalam hal ini Pemerintah Daerah bersama Direktorat Lalu Lintas menyiapkan marka jalan atau Ruang Henti Khusus (RHK) Sepeda Motor dengan model Starting Grid agar Pengendara satu dan penegendara lainnya dapat berjaga jarak. Oleh karena itu analisa efektivitas RHK tersebut dihitug sesuai dengan Tigkat keterisian Sepeda motor yang masuk dalam RHK dan berhenti tepat di Marka Starting Grid dan Tingkat Pelanggaran bagi sepeda motor yang masuk RHK atau di luar RHK yang tidak berhenti tepat di Marka Starting Grid tersebut.

\section{METEDOLOGI}

Metodologi penelitian merupakan suatu cara peneliti bekerja untuk memperoleh data yang dibutuhkan yang selanjutnya dapat digunakan untuk dianalisa sehingga memperoleh kesimpulan yang ingin dicapai dalam penelitian. Untuk mendapatkan data-data yang diperlukan dalam penelitian ini perlu diarahkan melalui survei lapangan guna mendapatkan data primer serta survey kepada instansi terkait guna rnendapatkan data sekunder. 


\section{Tempat Penelitian}

Penelitian ini akan dilaksanakan di simpang Lungsir (Taman Kota) di Jln. Dipenogoro - Jln. Dokter Susilo.

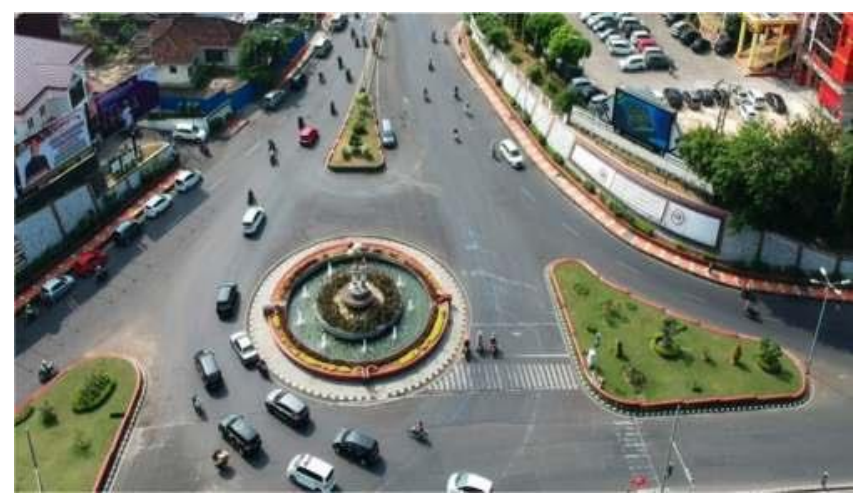

Gambar 1. Lokasi Penelitian

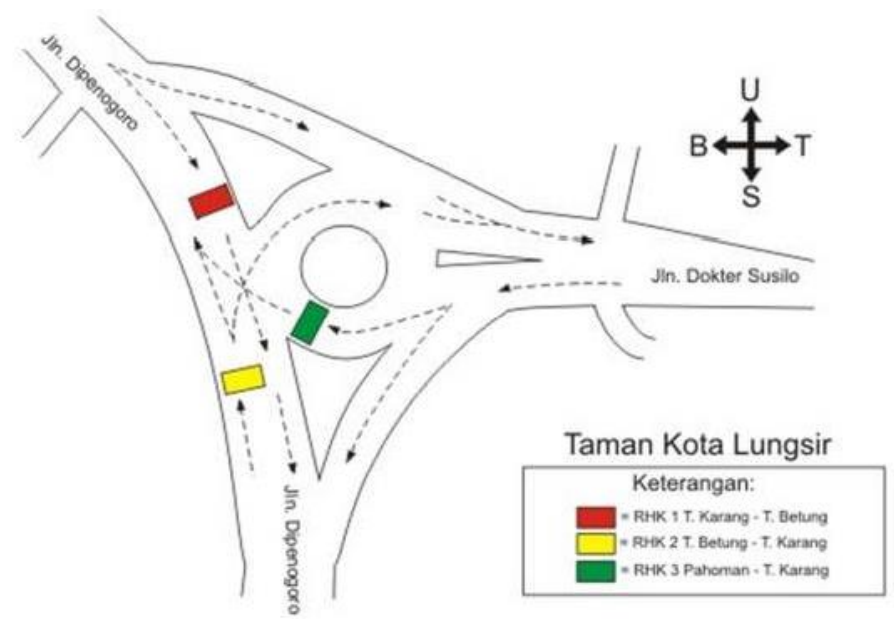

Gambar 2. Penampang RHK Dilokasi Penelitian

Penelitian dilakukan pada simpang Lungsir Taman Kota seperti terlihat pada Gambar 1 dan gambar 2, yaitu:

1. RHK 1 Jalan Dipenogoro dari Tanjung Karang - Teluk Betung

2. RHK 2 Jalan Dipenogoro dari Teluk Betung - Tanjung Karang

3. RHK 3 Jalan Dokter Susilo dari Pahoman - Tanjung Karang

\section{Waktu Penelitian}

Waktu penelitian ini dilakukan pada Weekend dan Weekdays dan pada jam sibuk yaitu :
1. Weekend, Hari Sabtu, 16 Januari 2021 pada Pagi jam 06.00 - 08.00, Siang jam 12.00 - 14.00 dan Sore jam $16.00-18.00$

2. Weekdays, Hari Senin, 18 Januari 2021 pada Pagi jam 06.00 - 08.00, Siang jam $12.00-14.00$ dan Sore jam $16.00-18.00$

\section{Teknik Pengumpulan Data}

Pengumpulan data dalam penelitian ini bertujuan untuk mencari data-data yang di butuhkan sesuai dengan literatur atau metode pelaksanaanya dari berbagai sumber, dari data tersebut terdapat dua data yaitu :

1. Data Primer

Data primer dalam penelitian ini didapat dengan cara:

a. Survei Pengguna RHK yaitu dengan cara mengehitung berapa pengguna jalan yang berada didalam atau diluar RHK

b. Survei Geometri Simpang yaitu mengukur geometri simpang menggunakan meteran berapa panjang dan lebar jalur maupun lajur simpang

c. Survei Geometri RHK yaitu mengukur ukuran RHK menggunakan meteran berapa panjang dan lebar RHK tersebut sesuai dengan peraturan PDT 2015 atau tidak.
d. Data Primer

2. Data Sekunder

Data Sekunder dalam penelitian ini didapat dengan cara:

a. Membaca dan mengambil data dari MKJI (Manual Kapasitas Jalan Indonesia)

b. Mengambil data dari PDT 2012 tentang RHK

c. Mengambil data dari PDT 2015 tentang RHK 


\section{Analisis Data}

Analisis Data adalah sebuah proses menganalisis data yang sudah kita rencanakan dan kita kumpulkan. Dalam penelitian ini terdapat beberapa yang akan kita analisis yaitu :

a. Perhitungan RHK Kondisi Normal yaitu perhitungan dengan cara mengukur efektivitas RHK agar kita dapat mengetahui RHK dalam kondisi efktif atau tidak.

b. Perhitungan Volume RHK yaitu menghitung volume untuk mengetahui terjadi penumpukan kendaraan sepeda motor atau tidak, perhitungan ini bertujuan untuk mengevaluasi kinerja RHK.

c. Perhitungan tingkat keberhasilan RHK yaitu tingkat keberhasilan RHK dapat kita lihat setelah menghitung dari kondisi normal atau efektivitas dan menghitung volume agar kita dapat mengevaluasi kinerja RHK dan akhirnya kita tahu tingkat keberhasilan RHK.

\section{HASIL DAN PEMBAHASAN}

\section{Survei Geometri RHK}

Survei Geometri RHK yaitu dengan cara mengukur lebar dan panjang ruang RHK, Berikut adalah gambar RHK :

1. Detail Geometri dan Dokumentasi Lokasi RHK 1 Jalan Dipenogoro dari arah Tanjung Karang - Teluk Betung dengan Lebar RHK 8,85 m, panjang RHK 8,85 m dan 17 Marka Starting Grid.

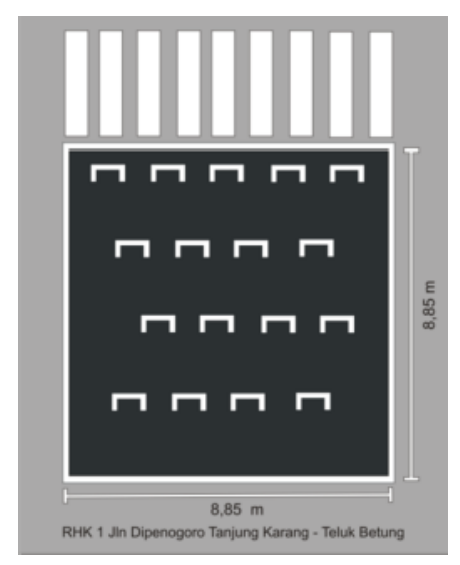

Gambar 3. Detail Geometri RHK 1

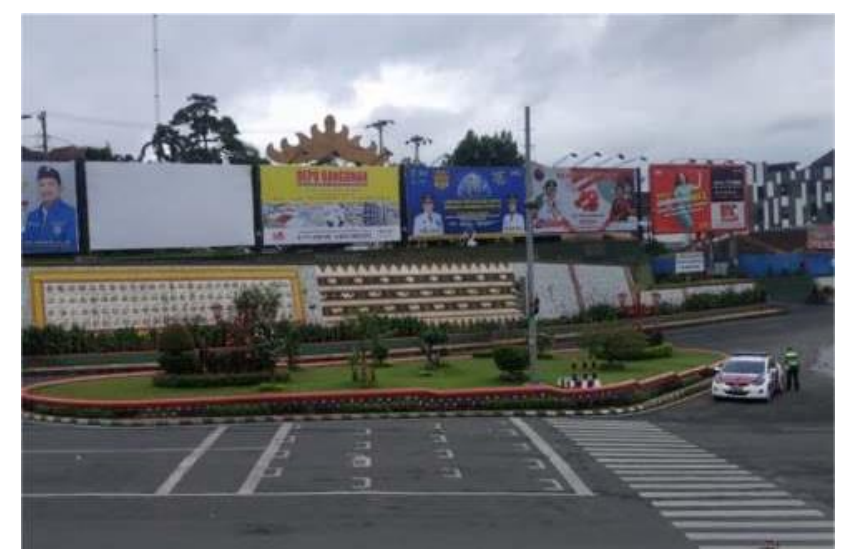

Gambar 4. Dokumentasi Lokasi RHK 1

2. Detail Geometri dan Dokumentasi Lokasi RHK 2 Jalan Dipenogoro dari arah Teluk Betung - Tanjung Karang, dengan lebar RHK 6,35m, panjang 6,16 $\mathrm{m}$ dan 9 Marka Starting Grid.

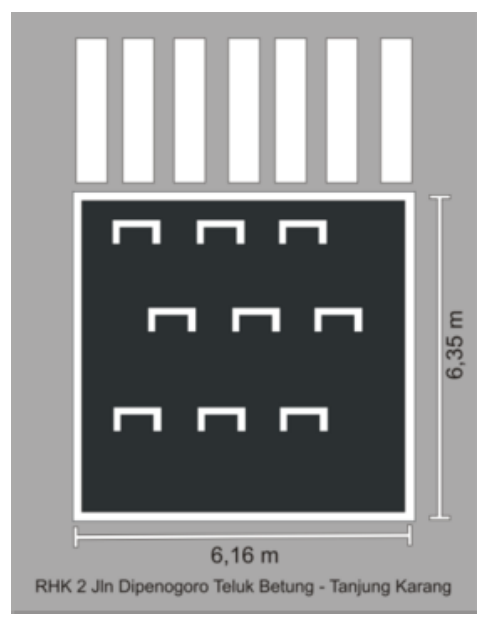

Gambar 5. Detail Geometri RHK 2 


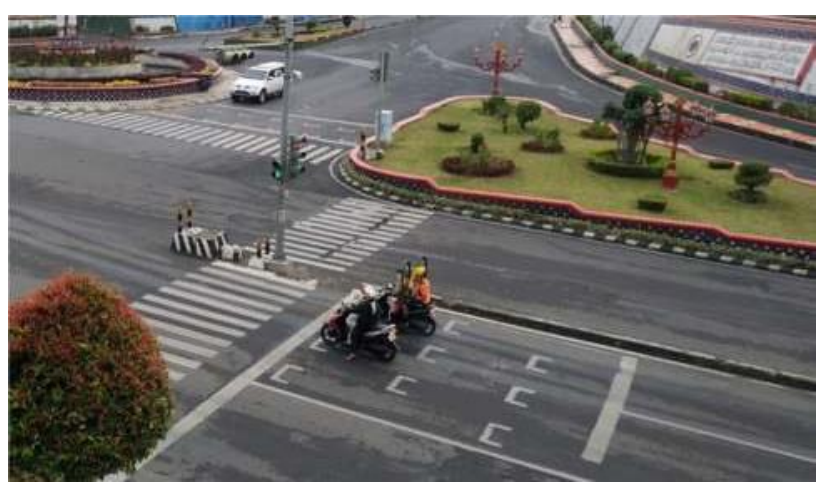

Gambar 6. Dokumentasi Lokasi RHK 2

3. Detail Geometri dan Dokumentasi Lokasi RHK 3 Jalan Dokter Susilo dari arah Pahoman - Tanjung Karang, dengan lebar 4,4 m, panjang 11,3m dan11 Marka Starting Grid.

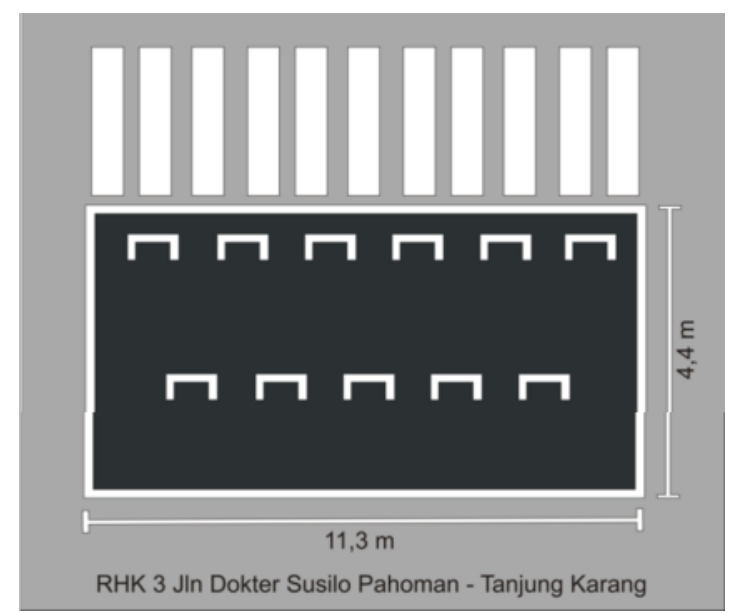

Gambar 7. Detail Geometri RHK 3

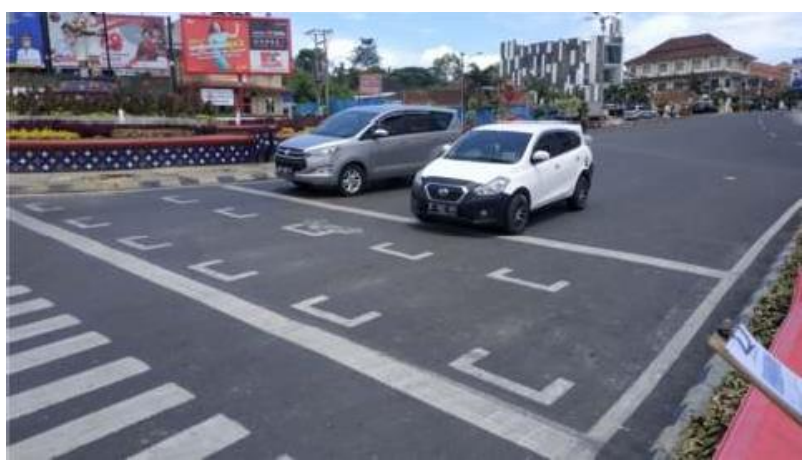

Gambar 8. Dokumentasi Lokasi RHK 3

Survei Geometri lebar dan panjang Marka Starting Grid pada ruang RHK, dengan lebar $0,45 \mathrm{~m}$ dan panjang $0,85 \mathrm{~m}$ Berikut detail gambar Marka Starting Grid :

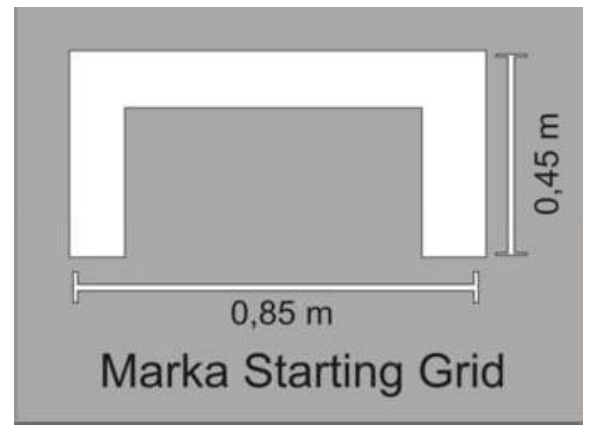

Gambar 9. Detail Geometri Marka Starting Grid

\section{Tingkat Keterisian RHK dengan Marka Starting Grid}

Tingkat Keterisian RHK Sepeda Motor dilihat dari berapa banyak sepeda motor yang berhenti tepat di marka Starting Grid. Berikut tabel Tingkat Keterisian RHK Sepeda Motor dilihat dari berapa banyak sepeda motor yang berhenti tepat dan dilihat dari berapa banyak sepeda motor dalam seluruh fase. Berikut Tabel Keterisian RHK :

1. Tingkat Keterisian RHK 1 Jalan Dipenogoro dari arah Tanjung Karang - Teluk Betung

Tabel 1. Tingkat Keterisian RHK 1

\begin{tabular}{|c|c|c|c|c|c|}
\hline \multicolumn{6}{|c|}{ WEEKEND (SABTU, 16 JANUARI 2021) } \\
\hline \multirow[t]{2}{*}{ No } & \multirow[t]{2}{*}{ Waktu } & \multirow[t]{2}{*}{$\begin{array}{l}\text { Jumlah } \\
\text { Fase }\end{array}$} & $\begin{array}{c}\text { Jumlah Sepeda } \\
\text { Motor didalam RHK } \\
\text { selama2Jam }\end{array}$ & $\begin{array}{l}\text { Jumlah Sepeda } \\
\text { Motorkeseluruhan } \\
\text { Faseselama2Jam }\end{array}$ & \multirow[t]{2}{*}{$\begin{array}{l}\text { Tingkat } \\
\text { Keterisian }\end{array}$} \\
\hline & & & (Unit) & (Unit) & \\
\hline 1 & PAGI Jam 06.00 sampai 08.00 & 87 & 500 & 697 & $71,74 \%$ \\
\hline 2 & SIANG Jam 12.00 sampai 14.00 & 87 & 428 & 774 & $55,30 \%$ \\
\hline 3 & SORE Jam 16.00 sampai 18.00 & 87 & 461 & 767 & $60,10 \%$ \\
\hline \multicolumn{6}{|c|}{ WEEKDAY (SENIN, 18 JANUARI 2021) } \\
\hline \multirow[t]{2}{*}{ No } & \multirow[t]{2}{*}{ Waktu } & \multirow[t]{2}{*}{$\begin{array}{l}\text { Jumlah } \\
\text { Fase }\end{array}$} & \begin{tabular}{|c|} 
Jumlah Sepeda \\
Motor didalam RHK \\
selama 2 Jam
\end{tabular} & $\begin{array}{l}\text { Jumlah Sepeda } \\
\text { Motorkeseluruhan } \\
\text { Fase selama } 2 \text { Jam }\end{array}$ & \multirow[t]{2}{*}{$\begin{array}{l}\text { Tingkat } \\
\text { Keterisian }\end{array}$} \\
\hline & & & (Unit) & (Unit) & \\
\hline 1 & PAGI Jam 06.00 sampai 08.00 & 87 & 644 & 719 & $89,57 \%$ \\
\hline 2 & SIANG Jam 12.00 sampai 14.00 & 87 & 515 & 824 & $62,50 \%$ \\
\hline 3 & SORE Jam 16.00 sampai 18.00 & 87 & 542 & 1063 & $50,99 \%$ \\
\hline
\end{tabular}

Dari beberapa hasil survey dalam waktu Pagi, Siang dan Sore dapat disimpulkan bahwa Tingkat Keterisian RHK sepeda motor nilai tertinggi keterisian RHK sepeda 
motor pada Pagi jam 06.00 - 08.00 sebesar 71,74 \% pada Weekend Sabtu tanggal 16 Januari 2021. Dan pada Weekday Senin tanggal 18 Januari 2021 hasil survey dalam waktu Pagi, Siang dan Sore dapat disimpulkan bahwa Tingkat Keterisian RHK sepeda motor nilai tertinggi keterisian RHK sepeda motor pada Pagi jam 06.00 - 08.00 sebesar $89,57 \%$.

2. Tingkat Keterisian RHK 2 Jalan Dipenogoro dari arah Teluk Betung - Tanjung Karang.

Tabel 2. Tingkat Keterisian RHK 2

\begin{tabular}{|c|c|c|c|c|c|}
\hline \multicolumn{6}{|c|}{ WEEKEND (SABTU, 16 JANUARI 2021) } \\
\hline \multirow[t]{2}{*}{ № } & \multirow[t]{2}{*}{ Waktu } & \multirow[t]{2}{*}{$\begin{array}{l}\text { Jumlah } \\
\text { Fase }\end{array}$} & \begin{tabular}{|c|} 
Jumlah Sepeda \\
Motordidalam RHK \\
selama2Jam \\
\end{tabular} & $\begin{array}{l}\text { Jumlah Sepeda } \\
\text { Motor Keseluruhan } \\
\text { Fase selama } 2 \text { Jam }\end{array}$ & \multirow[t]{2}{*}{$\begin{array}{l}\text { Tingkat } \\
\text { Keterisian }\end{array}$} \\
\hline & & & (Unit) & (Unit) & \\
\hline 1 & PAGI Jam 06.00 sampai 08.00 & 88 & 485 & 670 & $72,39 \%$ \\
\hline 2 & SIANG Jam 12.00 sampai 14.00 & 88 & 283 & 726 & $38,98 \%$ \\
\hline 3 & SORE Jam 16.00 sampai 18.00 & 88 & 303 & 825 & $36,73 \%$ \\
\hline \multicolumn{6}{|c|}{ WEEKDAY (SENIN, 18 JANUARI 2021) } \\
\hline \multirow[t]{2}{*}{ № } & \multirow[t]{2}{*}{ Waktu } & \multirow[t]{2}{*}{$\begin{array}{l}\text { Jumlah } \\
\text { Fase }\end{array}$} & \begin{tabular}{|c|} 
Jumlah Sepeda \\
Motordididalam RHK \\
selama2Jam
\end{tabular} & $\begin{array}{l}\text { Jumlah Sepeda } \\
\text { Motor keseluruhan } \\
\text { Fase selama } 2 \text { Jam }\end{array}$ & \multirow[t]{2}{*}{$\begin{array}{l}\text { Tingkat } \\
\text { Keterisian }\end{array}$} \\
\hline & & & (Unit) & (Unit) & \\
\hline 1 & PAGI Jam 06.00 sampai 08.00 & 88 & 272 & 751 & $36,22 \%$ \\
\hline 2 & SIANG Jam 12.00 sampal 14.00 & 88 & 360 & 750 & $48,00 \%$ \\
\hline 3 & SORE Jam 16.00 sampai 18.00 & 88 & 377 & 979 & $38,51 \%$ \\
\hline
\end{tabular}

Dari beberapa hasil survey dalam waktu Pagi, Siang dan Sore dapat disimpulkan bahwa Tingkat Keterisian RHK sepeda motor nilai tertinggi keterisian RHK sepeda motor pada Pagi jam 06.00 - 08.00 sebesar 72,39 \% pada Weekend Sabtu tanggal 16 Januari 2021. Dan pada Weekday Senin tanggal 18 Januari 2021. hasil survey dalam waktu Pagi, Siang dan Sore dapat disimpulkan bahwa Tingkat Keterisian RHK sepeda motor nilai tertinggi keterisian RHK sepeda motor pada Siang jam 12.00 14.00 sebesar $48 \%$.

3. Tingkat Keterisian RHK 3 Jalan Dokter Susilo dari arah Pahoman Tanjung Karang

Tabel 3. Tingkat Keterisian RHK 3

\begin{tabular}{|c|c|c|c|c|c|}
\hline \multicolumn{6}{|c|}{ WEEKEND (SABTU, 16 JANUARI 2021) } \\
\hline \multirow[t]{2}{*}{ No } & \multirow[t]{2}{*}{ Waktu } & \multirow[t]{2}{*}{$\begin{array}{l}\text { Jumlah } \\
\text { Fase }\end{array}$} & $\begin{array}{l}\text { Jumlah Sepeda } \\
\text { Motordidalam RHK } \\
\text { selama 2Jam }\end{array}$ & $\begin{array}{l}\text { Jumlah Sepeda } \\
\text { Motor Keseluruhan } \\
\text { Fase selama2Jam }\end{array}$ & \multirow[t]{2}{*}{$\begin{array}{l}\text { Tingkat } \\
\text { Keterisian }\end{array}$} \\
\hline & & & (Unit) & (Unit) & \\
\hline 1 & PAGI Jam O6.00 sampai 08.00 & 91 & 443 & 664 & $66,72 \%$ \\
\hline 2 & SIANG Jam 12.00 sampaa 14.00 & 91 & 219 & 300 & $73,00 \%$ \\
\hline 3 & SORE Jam 16.00 sampai 18.00 & 91 & 226 & 331 & $68,28 \%$ \\
\hline \multicolumn{6}{|c|}{ WEEKDAY (SENIN, 18 JANUARI 2021) } \\
\hline \multirow[t]{2}{*}{ No } & \multirow[t]{2}{*}{ Waktu } & \multirow[t]{2}{*}{$\begin{array}{c}\text { Jumlah } \\
\text { Fase }\end{array}$} & $\begin{array}{l}\text { Jumlah Sepeda } \\
\text { Motordidalam RHK } \\
\text { selama 2Jam }\end{array}$ & $\begin{array}{l}\text { Jumlah Sepeda } \\
\text { Motor Keseluruhan } \\
\text { Fase selama2Jam }\end{array}$ & \multirow[t]{2}{*}{$\begin{array}{l}\text { Tinghat } \\
\text { Keterisian }\end{array}$} \\
\hline & & & (Unit) & (Unit) & \\
\hline 1 & PAGI Jam 06.00 sampai 08.00 & 91 & 288 & 505 & $57,03 \%$ \\
\hline 2 & SIANG Jam 12.00 sampai 14.00 & 91 & 277 & 432 & $64,12 \%$ \\
\hline 3 & SORE Jam 16.00 sampai 18.00 & 91 & 397 & 682 & $58,21 \%$ \\
\hline
\end{tabular}

Dari beberapa hasil survey dalam waktu Pagi, Siang dan Sore dapat disimpulkan bahwa Tingkat Keterisian RHK sepeda motor nilai tertinggi keterisian RHK sepeda motor pada Siang jam 12.00 14.00 sebesar $73 \%$ pada Weekend Sabtu tanggal 16 Januari 2021. Dan pada Weekday Senin tanggal 18 Januari 2021. hasil survey dalam waktu Pagi, Siang dan Sore dapat disimpulkan bahwa Tingkat Keterisian RHK sepeda motor nilai tertinggi keterisian RHK sepeda motor pada Siang jam 12.00 14.00 sebesar $64,12 \%$. 
Tingkat Pelanggaran RHK dengan

\section{Marka Starting Grid}

Tingkat Pelanggaran RHK Sepeda Motor dilihat dari berapa banyak sepeda motor yang tidak berhenti tepat di marka Starting Grid atau berada didalam RHK tetapi tidak berhenti tepat di marka Starting Grid dan sepeda motor yang berada diluar RHK. Berikut Tabel Tingkat Pelanggaran RHK Sepeda Motor :

1. Tingkat Pelanggaran RHK 1 Jalan Dipenogoro dari arah Tanjung Karang - Teluk Betung

Tabel 4. Tingkat Pelanggaran RHK 1

\begin{tabular}{|c|c|c|c|c|c|}
\hline \multicolumn{6}{|c|}{ WEEKEND (SABTU, 16 JANUARI 2021) } \\
\hline \multirow[t]{2}{*}{ No } & \multirow[t]{2}{*}{ Waktu } & \multirow[t]{2}{*}{$\begin{array}{l}\text { Jumlah } \\
\text { Fase }\end{array}$} & $\begin{array}{l}\text { Jumlah Pelanggaran } \\
\text { SepedaMotortidakdi } \\
\text { RHKselama2jam }\end{array}$ & $\begin{array}{c}\text { Jumlah Sepeda Motor } \\
\text { keseluruhan Fase } \\
\text { selama } 2 \text { Jam }\end{array}$ & \multirow[t]{2}{*}{$\begin{array}{l}\text { Tingkat } \\
\text { Pelanggaran }\end{array}$} \\
\hline & & & (Unit) & (Unit) & \\
\hline 1 & PAGI Jam 06.00 sampai 08.00 & 87 & 197 & 697 & $28,26 \%$ \\
\hline 2 & SIANGJam 12.00sampai 14.00 & 87 & 346 & 774 & $44,70 \%$ \\
\hline 3 & SOREJam16.00sampa 18.00 & 87 & 306 & 767 & $39,90 \%$ \\
\hline \multicolumn{6}{|c|}{ WEEKDAY (SENIN, 18 JANUARI 2021) } \\
\hline \multirow[t]{2}{*}{ No } & \multirow[t]{2}{*}{ Waktu } & \multirow[t]{2}{*}{$\begin{array}{l}\text { Jumlah } \\
\text { Fase }\end{array}$} & $\begin{array}{l}\text { Jumlah Pelanggaran } \\
\text { SepedaMotortidakdi } \\
\text { RHKselama2jam }\end{array}$ & $\begin{array}{c}\text { Jumlah Sepeda Motor } \\
\text { keseluruhan Fase } \\
\text { selama } 2 \text { Jam }\end{array}$ & \multirow[t]{2}{*}{$\begin{array}{r}\text { Tingkat } \\
\text { Pelanggaran }\end{array}$} \\
\hline & & & (Unit) & (Unit) & \\
\hline 1 & PAGI Jam 06.00 sampai 08.00 & 87 & 75 & 719 & $10,43 \%$ \\
\hline 2 & SIANGJam 12.00sampai 14.00 & 87 & 309 & 824 & $37,50 \%$ \\
\hline 3 & SOREJam 16.00sampai 18.00 & 87 & 521 & 1063 & $49,01 \%$ \\
\hline
\end{tabular}

Dari beberapa hasil survey dalam waktu Pagi, Siang dan Sore dapat disimpulkan bahwa Tingkat Pelanggaran RHK sepeda motor nilai tertinggi Pelanggaran RHK sepeda motor pada Siang jam 12.00 -

14.00 sebesar 44,7\% pada Weekend Sabtu tanggal 16 Januari 2021. Dan pada Weekday Senin tanggal 18 Januari 2021 hasil survey dalam waktu Pagi, Siang dan Sore dapat disimpulkan bahwa Tingkat Pelanggaran RHK sepeda motor nilai tertinggi Pelanggaran RHK sepeda motor pada Sore Jam 16.00 - 18.00 sebesar $49,01 \%$
2. Tingkat Pelanggaran RHK 2 Jalan Dipenogoro dari arah Teluk Betung - Tanjung Karang

Tabel 5. Tingkat Pelanggaran RHK 2

\begin{tabular}{|c|c|c|c|c|c|}
\hline \multicolumn{6}{|c|}{ WEEKEND (SABTU, 16 JANUARI 2021) } \\
\hline \multirow[t]{2}{*}{ No } & \multirow[t]{2}{*}{ Waktu } & \multirow[t]{2}{*}{$\begin{array}{r}\text { Jumlah } \\
\text { Fase }\end{array}$} & $\begin{array}{l}\text { Jumlah Pelanggaran } \\
\text { Sepeda Motortidakdi } \\
\text { RHKselama2jam }\end{array}$ & $\begin{array}{c}\text { Jumlah Sepeda Motor } \\
\text { keseluruhan Fase } \\
\text { selama } 2 \text { Jam }\end{array}$ & \multirow[t]{2}{*}{$\begin{array}{c}\text { Tingkat } \\
\text { Pelanggaran }\end{array}$} \\
\hline & & & (Unit) & (Unit) & \\
\hline 1 & PAGI Jam 06.00 sampai 08.00 & 88 & 185 & 670 & $27,61 \%$ \\
\hline 2 & SIANGJam 12.00sampai 14.00 & 88 & 443 & 726 & $61,02 \%$ \\
\hline 3 & SOREJam 16.00sampai 18.00 & 88 & 522 & 825 & $63,27 \%$ \\
\hline \multicolumn{6}{|c|}{ WEEKDAY (SENIN, 18 JANUARI 2021) } \\
\hline \multirow[t]{2}{*}{ No } & \multirow[t]{2}{*}{ Waktu } & \multirow[t]{2}{*}{$\begin{array}{l}\text { Jumlah } \\
\text { Fase }\end{array}$} & $\begin{array}{l}\text { Jumlah Pelanggaran } \\
\text { SepedaMotortidakdi } \\
\text { RHKselama2jam }\end{array}$ & $\begin{array}{c}\text { Jumlah Sepeda Motor } \\
\text { keseluruhan Fase } \\
\text { selama } 2 \text { Jam }\end{array}$ & \multirow[t]{2}{*}{$\begin{array}{l}\text { Tingkat } \\
\text { Pelanggarar }\end{array}$} \\
\hline & & & (Unit) & (Unit) & \\
\hline 1 & PAGI Jam 06.00 sampai 08.00 & 88 & 479 & 751 & $63,78 \%$ \\
\hline 2 & SIANGJam 12.00sampai 14.00 & 88 & 390 & 750 & $52,00 \%$ \\
\hline 3 & SOREJam16.00sampai 18.00 & 88 & 602 & 979 & $61,49 \%$ \\
\hline
\end{tabular}

Dari beberapa hasil survey dalam waktu Pagi, Siang dan Sore dapat disimpulkan bahwa Tingkat Pelanggaran RHK sepeda motor nilai tertinggi Pelanggaran RHK sepeda motor pada Sore jam 16.00 - 18.00 sebesar $63,27 \%$ pada Weekend Sabtu tanggal 16 Januari 2021. Dan pada Weekday Senin tanggal 18 Januari 2021. hasil survey dalam waktu Pagi, Siang dan Sore dapat disimpulkan bahwa Tingkat Pelanggaran RHK sepeda motor nilai tertinggi Pelanggaran RHK sepeda motor pada Pagi Jam 06.00 - 08.00 sebesar $63,78 \%$.

3. Tingkat Pelanggaran RHK 3 Jalan Dokter Susilo dari arah Pahoman Tanjung Karang 
Tabel 4. Tingkat Pelanggaran RHK 3

\begin{tabular}{|c|c|c|c|c|c|}
\hline \multicolumn{6}{|c|}{ WEEKEND (SABTU, 16 JANUARI 2021) } \\
\hline \multirow[t]{2}{*}{ No } & \multirow[t]{2}{*}{ Waktu } & \multirow[t]{2}{*}{$\begin{array}{r}\text { Jumlah } \\
\text { Fase }\end{array}$} & $\begin{array}{l}\text { Jumlah Pelanggaaran } \\
\text { Sepeda Motor tidak di } \\
\text { RHK selama } 2 \text { jam }\end{array}$ & $\begin{array}{c}\text { Jumlah Sepeda Motor } \\
\text { keseluruhan Fase } \\
\text { selama } 2 \text { Jam }\end{array}$ & \multirow[t]{2}{*}{$\begin{array}{l}\text { Tingkat } \\
\text { Pelanggaran }\end{array}$} \\
\hline & & & (Unit) & (Unit) & \\
\hline 1 & PAGI Jam 06.00 sampai 08.00 & 91 & 221 & 664 & $33,28 \%$ \\
\hline 2 & SIANG Jam 12.00 sampai 14.00 & 91 & 81 & 300 & $27,00 \%$ \\
\hline 3 & SORE Jam 16.00 sampai 18.00 & 91 & 105 & 331 & $31,72 \%$ \\
\hline \multicolumn{6}{|c|}{ WEEKDAY(SENIN, 18 JANUARI 2021) } \\
\hline \multirow[t]{2}{*}{ No } & \multirow[t]{2}{*}{ Waktu } & $\begin{array}{r}\text { Jumlah } \\
\text { Fase }\end{array}$ & $\begin{array}{l}\text { Jumlah Pelanggaran } \\
\text { Sepeda Motor tidak } \\
\text { di RHK selama } 2 \\
\text { jam }\end{array}$ & $\begin{array}{c}\text { Jumlah Sepeda Motor } \\
\text { keseluruhan Fase } \\
\text { selama } 2 \text { Jam }\end{array}$ & \multirow[t]{2}{*}{$\begin{array}{l}\text { Tingkat } \\
\text { Pelanggaran }\end{array}$} \\
\hline & & & (Unit) & (Unit) & \\
\hline 1 & PAGI Jam 06.00 sampai 08.00 & 91 & 217 & 505 & $42,97 \%$ \\
\hline 2 & SIANG Jam 12.00 sampai 14.00 & 91 & 155 & 432 & $35,88 \%$ \\
\hline
\end{tabular}

Dari beberapa hasil survey dalam waktu Pagi, Siang dan Sore dapat disimpulkan bahwa Tingkat Pelanggaran RHK sepeda motor nilai tertinggi Pelanggaran RHK sepeda motor pada Pagi Jam 06.00 - 08.00 sebesar 33,28\% pada Weekend Sabtu tanggal 16 Januari 2021. Dan pada Weekday Senin tanggal 18 Januari 2021 hasil survey dalam waktu Pagi, Siang dan Sore dapat disimpulkan bahwa Tingkat Pelanggaran RHK sepeda motor nilai tertinggi Pelanggaran RHK sepeda motor pada Pagi Jam 06.00 - 08.00 sebesar $42,97 \%$.

\section{Kesimpulan}

Berdasarkan hasil analisa efektivitas RHK (Ruang Henti Khusus) Sepeda Motor model marka Starting Grid pada simpang bersinyal di taman Muli - Mekhanai (Taman Kota Lungsir) dimasa Pandemi COVID - 19 yang dilakukan dapat disimpulkan bahwa :

1. Penerapan RHK dengan marka Starting Grid pada RHK 1 Jalan Dipenogoro dari arah Tanjung Karang - Teluk Betung dan RHK 3 Jalan
Dokter Susilo dari arah Pahoman Tanjung Karang dapat mengurangi panjangnya antrian sedangakan pada RHK 2 Jalan Dipenogoro dari arah Teluk Betung - Tanjung karang tidak dapat mengurangi panjangnya antrian. Dibuktikan dengan survey tingkat keterisian RHK dan Tingkat pelanggaran RHK

2. Dari Hasil penelitian ini didapatkan Tingkat keterisian Pada RHK 1 Jalan Dipenogoro dari arah Tanjung karang - Teluk Betung, RHK 2 Jalan Dipenogoro dari arah Teluk Betung Tanjung Karang dan RHK 3 Jalan Dokter Susilo dari arah Pahoman Tanjung Karang

3. Dari Hasil penelitian ini efektivitas RHK ditinjau dari Tingkat Keterisian RHK berbanding dengan Tingkat Pelanggaran RHK jika Tingkat Keterisian RHK lebih besar (>) dari Tingkat Pelanggaran maka RHK dikatakan berhasil, Jika sebaliknya tingkat keterisian lebih kecil $(<)$ dari tingkat pelanggaran maka RHK tidak berhasil. Jadi Pada pada RHK 1 Jalan Dipenogoro dari arah Tanjung Karang - Teluk Betung dan RHK 3 Jalan Dokter Susilo dari arah Pahoman Tanjung Karang RHK dengan Marka Starting Grid bekerja dengan efektif, sedangakan pada RHK 2 Jalan Dipenogoro dari arah Teluk Betung Tanjung karang RHK dengan Marka Starting Grid tidak efektif.

\section{Saran}

Saran yang dianjurkan berdasarkan penelitian dan analisis, yaitu :

1. Pengguna Sepeda Motor berperan penting dalam kinerja simpang bersinyal oleh karena itu 
pemerintah membuat teknologi RHK (Ruang Henti Khusus) Sepeda motor. Dan pada Tahun 2020 - 2021 bulan februari ini Indonesia dilanda sebuah musibah yaitu Virus COVID - 19 dan sebab itu Pemerintah Kementrian Kesehatan Menganjurkan masyarakat agar berjaga jarak dan Polantas beserta Dishub bekerjasama untuk menerapakan RHK dengan model marka Starting Grid agar para pengguna RHK atau pengendara sepeda motor tetap menjaga jarak satu sama lain. Oleh karena itu kesadaran masyrakat untuk mematuhi Protokol kesehatan dan peraturan peraturan pemerintah yang berlaku adalah faktor utama agar RHK tersebut berjalan efektif dan efisien.

2. Saran Khusus untuk RHK 2 Jalan Dipenogoro dari arah Teluk Betung - Tanjung Karang untuk ditambah Jumlah Marka Starting Grid dikarenakan jumlah marka yang sedikit dan penggunanya berlebihan maka harus ditinjau ulang dan ditambah jumlah markanya agara kinerja persimpangan dan RHK tersebut dapat berjalan dengan baik.

3. Untuk RHK dengan model marka Starting Grid Ini perlu dintinjau kembali agar peraturan untuk diterapkan nya Marka Starting Grid ini dapat dilaksanakan dan disosialisasikan ke masyarakat.

\section{DAFTAR PUSTAKA}

Badan Penelitian dan Pengembangan Pekerjaan Umum dan Perumahan Rakyat. Pelatihan
(2018), Monitoring dan Evaluasi RHK

Badan Pusat Statistik Provinsi Lampung (2017), Kepadatan Penduduk di Provinsi Lampung

Balai Teknik Lalu Lintas dan Lingkungan Jalan (2018), Simpang Bersinyal dan Sistem Jaringan Jalan

$$
\begin{gathered}
\text { Kementrian Pekerjaan Umum 2012, } \\
\text { Perancangan Ruang Henti } \\
\text { Khusus }(\text { RHK) Sepeda Motor }
\end{gathered}
$$

Kementrian Pekerjaan Umum 2015, Perancangan Ruang Henti Khusus (RHK) Sepeda Motor

Ketut Anggar Saeprima (2014), Analisa Efektivitas RHK pada simpang bersinyal di Tugu Adipura

;Sarjana Teknik Sipil

Universitas Bandar Lampung

Manual Kapasitas Jalan Indonesia (1997), Manual untuk kegiatan analisis, perencanaan, perancangan, dan operasi lalu lintas jalan.

Pusat Penelititan Jalan dan Jembatan (2018), Perilaku Lalu Lintas Pada Simpang Bersinyal

Surat Edaran Mentri PUPR No.52/SE/M/2015 Tentang, Pedoman Perancangan Ruang Henti Khusus (RHK) Sepeda motor pada simpang bersinyal dikawasan perkotaan

S.P Siagian (2008:77), Kriterian dan ukuran mengenai pencapaian tujuan efektif atau tidak 